Oct 2020. Forthcoming in Economy es Society.

\title{
FROM SOCIAL SECURITY TO STATE-SANCTIONED INSECURITY: HOW WELFARE REFORM MIMICS THE COMMODIFICATION OF LABOUR THROUGH GREATER STATE INTERVENTION*
}

\author{
Insa $\mathrm{Koch}^{\dagger}$ and Aaron Reeves ${ }^{\ddagger}$
}

October 26, 2020

\begin{abstract}
:
Policy makers seeking to reform social security systems have frequently confronted a central tension: how to reconcile welfare retrenchment with the political challenges of implementing unpopular reforms. One way in which policy makers have responded to this tension is by repurposing existing institutions to serve new ends. We investigate the system of Universal Credit (UC) in the UK as an example of such a 'conversion'. UC expands the reach of 'active citizenship' policies to a much larger population than ever before. However, far from producing uniform outcomes, UC's implementation has been marked by chaos and ultimately failure for individuals and communities. We argue that UC exemplifies a broader shift from social security to state-sanctioned social insecurity as policy reforms come to mimic the insecurities and risks commonly associated with the market.
\end{abstract}

\section{INTRODUCTION}

The organising logic of social security systems is currently marked by a tension. On the one hand, unlike the 'classical' arrangements of high-income post-war welfare states, social security policy is no longer framed primarily in terms of decommodifying labour and collectivising the risks associated with capitalism (Esping-Andersen, 1990). Instead, it is predominantly seen through its potential to create unsustainable public spending and high levels of public debt, or its unintended impact on welfare dependency (Hills, 2014). This discursive shift toward

\footnotetext{
*Insa Koch and Aaron Reeves are joint lead authors of this article, and both contributed equally.

'Department of Law, LSE, i. koch@lse. ac. uk

${ }^{\ddagger}$ Department of Social Policy and Intervention, University of Oxford, aaron . reeves@spi . ox . ac . uk
} 
welfare state retrenchment is manifest in reforms which have reduced government spending, recommodified labour, and privatised risks by reconfiguring the conditions of entitlements and the structure of financial support (Hills, 2011; Pierson, 1994; Timmins, 2017). On the other hand, however, implementing welfare state retrenchment has been far from easy (Hacker, 2004). Indeed, in many ways the basic contours of the social policy landscape remain relatively unchanged. This is particularly true if we look at overall public expenditure on social policies for most high-income countries, even those considered to be more liberal (or more commodified), such as the UK. This is because cuts are difficult to implement, as harms are typically concentrated on vulnerable groups, whereas the benefits politicians accrue by implementing such cuts are diffuse (Pierson, 1994).

In this paper, we analyse the design and implementation of Universal Credit (UC) in the United Kingdom to illustrate how this tension - between the resistance to privatising risks and the costs associated with welfare dependency - gets instantiated. Universal Credit has been described as 'one of the boldest and most radical reforms since Beveridge' because it streamlines the system of existing benefits, bringing together six different forms of social security into a single form of welfare (Timmins, 2017). This streamlining was intended to 'activate' citizens (moving them into employment) by making it easier to move between out-of-work and in-work benefits (Hills, 2014). But UC does not merely institutionalise a mantra of 'active citizenship'. On the contrary, we show the uneven, chaotic and at times outright disastrous effects of the roll-out of this most recent wave of welfare reforms. As people become unable to meet its requirements, they fall foul of the system of conditionality and sanctions, which is ultimately pushing many away from the labour market, while at the same time communities that have already been harshly hit by a decade of austerity are further destabilised by the individualising effects of a new digital welfare state.

Drawing upon a mixed-methods analysis that brings together existing quantitative research with original qualitative fieldwork, we argue that the efforts of politicians and policymakers to place 'active citizenship' more squarely at the heart of welfare states has fostered the kinds of insecurities commonly associated with commodifying labour, all while leaving the state's involvement in the lives of those affected largely intact. Unable to simply reduce welfare spending or recommodify labour entirely, policymakers have engaged in a process Thelen (2003) calls 'conversion', whereby the purposes of a policy or an institution are remade. In the context of UC, this means existing systems of social security are being reconstituted with the consequence that the machinery of the state is now assuming an ever more central role in creating uncertainty. Welfare conversion is not merely 'privatising risks', however, by exposing citizens to the insecurities associated with the market. Rather, we argue that these reforms are turning the state itself into the creator of certain risks by converting (whether intentionally or not) social security into a form of state-sanctioned social insecurity. This happens as particular state interventions - including those relating to work-related conditionality, sanctions, and the digitalization of the welfare state - have disproportionately affected some of the most vulnerable members of the population and further weakened the capacities for collective resistance in communities that have been most severely affected by welfare reforms.

Our analysis contributes to wider debates on the 'state of the welfare state' (Koch and James 
2020) by bringing perspectives from within the anthropology of the 'everyday state' (Alexander 2000; Fuller and Bénéï 2000; Koch 2018; Spencer 1997; Thelen et al 2014) to bear on social policy debates. Thus, although our focus is on a particular policy, we are not primarily interested in the policy itself. Rather, we go beyond traditional social policy perspectives by seeking to understand the social reality these policies create (Dubois, 2009). Methodologically, this leads us to start with how UC manifests itself in the lived experience of people subject to UC in order to identify its wider implications for relations between citizens, the state, and the market (Patrick, 2017). Our second, more conceptual contribution is to theorise UC as a form of policy conversion which arises from the historical tension between policies which seek (de-)commodify labour. Doing so allows us to develop an argument about a qualitative shift in welfare state making, one which both draws on older logics of commodification but which is also distinct in the way it intensifies these logics by turning the state itself into a dispenser of heightened risk. It is precisely this production of risks through the mechanism of the state, rather than the market as commonly assumed (Harvey 2007), that we refer to as 'state sanctioned insecurity' - a process which may well be representative of broader welfare developments in the years to come, and which raises the need for urgent political change.

\section{COMPETING LOGICS IN THE WELFARE STATE: BETWEEN DE-COM- MODIFYING LABOUR AND ENACTING WELFARE RETRENCHMENT}

While most countries share a commitment to ensuring a basic standard of living for citizens, societies' understanding of what constitutes 'bare life' changes over time (Agamben, 1998). This is true in the UK and many other high-income countries, where certain economic and social forces have reconfigured the assumptions people hold about their government's role in ensuring a basic standard of living. For example, one key dimension around which welfare states have been formed is the degree to which labour is de-commodified or not, that is, the degree to which households can maintain a socially acceptable standard of living independently of engaging in the labour market (Esping-Andersen 1990). In the UK specifically, the post-war welfare system which placed limits on the de-commodification of labour was premised on what TH Marshall called 'social rights' (Marshall 1950) - a belief in extending certain basic entitlements to all citizens, with benefits rooted in work (Kymlicka \& Norman, 1994). The UK, then, implemented a partial de-commodification of labour through ensuring some groups (such as the elderly and to some extent children) would not need to rely on wage labour for their livelihood (Timmins 2017). And yet, de-commodification was not extended to everyone. There have always been conditions attached to most forms of social security (Hills 2014). Those who failed to engage productively with the market have been subject to stigmatisation (McArthur and Reeves 2019) which helped legitimise the harsher forms of welfare conditionality applied to those lacking 'respectability' (Tyler 2020), including with respect to some of the most valued social goods, such as council housing (Koch 2018).

But it was only during the 1980s that the political impulse towards welfare retrenchment and the stigmatisation of those who continued to rely upon benefits became far more prominent (Clarke \& Newman 2012). Governments came to emphasise unsustainable levels of public spending and the belief that welfare regimes fostered a culture of dependency (Hills 2014; 
Somers \& Block 2005). Whereas the logic of 'social rights' had assumed the state would collectivise the risks associated with ill health, unemployment, and old age, the new logic of social security was one of 'privatising risks' through re-commodifying labour by exposing it to market forces more completely. This presumed a more residualised form of risk sharing, whereby individuals rather than collectives bear their costs. The interface between state and market was the central battleground on which policy conflicts were waged, with marketoriented approaches becoming ideologically dominant. Further, with the global financial crisis in 2008/2009, reducing government debts was made the key policy goal in many European countries (Clarke \& Newman 2012). Welfare recipients became the scapegoats, as they were seen to be the ones pushing up government spending, creating unsustainable levels of public debt through their unwillingness to work and threatening economic recovery. By stigmatising those on social security, the Conservative-led Coalition government elected in 2010 sought to legitimise policies intended to reduce government deficits by cutting public spending through policies like the bedroom tax and the benefit cap (Koch 2018) and through withdrawing funding from local communities (so-called 'austerity localism') (Lowndes \& Pratchett 2012).

And yet, the financial crisis on top of decades of neo-liberal reform did not simply do away with welfare states' commitment to collectivise risks associated with the free market. It did not suddenly alter the political calculus that had made re-commodification of labour difficult in the post-war decades, nor did it remove the powerful constituencies who were likely to fight retrenchment. Thus, while the ideational shift towards welfare retrenchment - increasingly prominent since the late 1970s - has led to real differences in how social policies are organised, there is also a surprising degree of stability in social welfare programmes, such as universal healthcare services, pensions, and working-age benefits (OECD 2019; Pierson 1994). Indeed, this shift was only successful in allowing the services provided and the protection offered to become devalued in real terms over time. Instead, welfare states have typically come to tackle the ensuing tensions through a mantra of 'active citizenship' (Reeves \& Loopstra 2017), which refers to the obligations on which entitlement to social security is predicated, and the forms of welfare conditionality that come with it. As a policy mantra, this has been central to social security provision at least since the 1990s, as people are typically only entitled to social security if they are active in a specific kind of way and failure to do so results in financial penalties (Timmins 2017). But, as we will see below, active citizenship has experienced a period of resurgence since the financial crisis where policies, including UC, have more explicitely linked welfare entitlement to different forms of conditionality.

In short, even just a cursory glance at the history of post-war social security policies reveals a central tension at the heart of the welfare state, in the UK and beyond: between an ever-greater drive to commodify labour, on the one hand, and governments' inability to completely remove the state from providing 'bare life' (Agamben, 1998), on the other. While in the 'classical' period of post-war British social democracy, this tension tended to be resolved in favour of the latter, more recently, political impetus has pursued an ideological agenda in line with the former. Yet, even today, a commitment to offering a minimum level of social security protection continues to exist, resulting in tensions that are instantiated in the mantra of 'active citizenship'. This, in turn, raises the question of how governments reconcile these tensions. We now turn to one way in which governments have attempted to do so through a process of adaptation that 
Thelen refers to as 'conversion' (2003), and illustrate this with reference to the case of UC. We will argue that despite important continuities in existing social security provisions, it is in redirecting policies towards new aims that policies like UC have impacted the lived experiences of citizens, thus also transforming relations between citizens, the market and the state in far more radical ways than anticipated by politicians and welfare reformers.

\section{UNIVERSAL CREDIT AS POLICY CONVERSION}

Policy change can occur in a number of ways, perhaps most radically through wholesale revolution and radical intervention (Hacker et al. 2015; Thelen 2003). But such substantial changes to existing systems are rare because they are difficult to implement. Instead, politicians are more commonly forced to rely on other mechanisms to push through changes that reflect shifting priorities or goals. One of these alternative processes is 'conversion' which, in Thelen's work (2003), occurs when states redirect existing institutions toward new aims or purposes. Converting policy to new ends does not rely on 'large-scale legislative reform' but instead it occurs through 'a set of decentralised and semi-autonomous processes of alteration' which work 'within existing policy bounds' (ibid.: 244). Conversion means that, on the face of it, policies look quite similar: many of the old institutions will continue to exist and certain features of the policy will remain unchanged. Another feature of policy conversion is that it does not typically rely on the direct input of voters, and if they enter the process at all, their voices tend to be primarily directed toward constraining certain aspects of the change. Thus, policy conversion is most likely to take place (as is commonly the case with welfare policy) when replacing existing systems would be costly and when political conditions militate against authoritative changes (Hacker, 2004). Conversion, then, is particularly common after major shifts in power (Hacker et al., 2015), when new policy actors are able to assume control of the machinery of the institution and direct it toward new goals (so-called 'actor discontinuity').

While 'conversion' occurs in all aspects of policy making, it is unsurprising that welfare states in particular have repeatedly witnessed periods of 'conversion.' As Pierson (1994) has argued, the high degree of continuity in welfare policy is partially explained by the political calculus involved in making such reforms. Cutting services usually harms people and there will be short-term costs associated with making some groups ineligible for social security. Moreover, the benefits associated with such changes can be rather diffuse. The political incentives for welfare retrenchment are low because politicians are likely to be blamed for creating harm but are unlikely to receive credit for the good they (in theory) produce. And even if a politician is willing to take that risk, the creation of social security also forges 'armies of beneficiaries' who are well-placed to resist such changes. Indeed, in the UK, the creation of the post-war welfare state itself is an example of conversion: policies that seemed to be the result of a Labour government putting socialist principles into effect, were to a great degree the legacy of a state which had been organized to fight a total war' (Atlee cited in Hacker et al 2015). More fundamentally, the British welfare state was always imbued with multiple, and at times conflicting, logics which underpin a diverse range of policy domains. As we have already seen, one fundamental tension that informs welfare states is the commitment to commodifying labour, on the one hand, and, on the other, the political difficulties of actually leaving people to make ends meet through the market alone - a tension that has resurfaced once more in the aftermath of 
the financial crisis.

In this paper, we analyse the consequences of one particular case of policy 'conversion': namely the British government's recent reform in social security called Universal Credit. UC represents a new attempt to re-centre the logic of 'active citizenship' within welfare policy, that is to convert existing social security to resolve the tension between welfare retrenchment and the state's commitment to provide a minimum level of social security for its most vulnerable citizens. UC is particularly interesting because it was pushed through following a major political shift brought about by the global financial crisis and the 2010 UK General Election. But it was not, at least in its original impetus, about cuts itself and in its earliest phase meant that UC generated cross party political support (Millar \& Bennett, 2017). It was also not demanded by voters. In fact, UC was not even included in the Conservative manifesto for the 2010 election and so the influence of voters on UC has been most keenly felt during the roll-out phase and therefore they have largely played a constraining role. On the face of it, the process of 'conversion' implied by UC has then constituted a straightforward endeavour. By placing the mantra of 'active citizenship' at its heart, UC has imposed the rules of work-related conditionality, sanctions, and a new system of digital welfare to an ever-greater part of the population. It has done so by moving both 'up' the income distribution (including not just those out of employment but also the working poor who rely upon top-up benefits) as well as across (by encompassing a greater range of benefits).

It would appear that UC fits a framework of governmentality, as a set of state-sanctioned processes or techniques, characterised by 'permanent vigilance, activity, and intervention' (Foucault, 2008: 132), and through which government attempt to alter the behaviour of citizens (Rose, O'Malley, \& Valverde, 2006). Here, it is the threat of deprivation - as well as the actual experience of being cut off from financial support (Watts \& Fitzpatrick, 2018) - that is intended to turn failed individuals into productive, and valued citizens in the manner envisaged by Foucault (2008). And yet, this is not the whole story. As is so frequently the case with policy interventions (Bear, 2013; Koch 2020; Shore \& Wright, 2003; Weszkalnys 2013), we argue that the story of UC's roll-out has, in fact, been far from neat. Our evidence shows that in some cases, UC has also failed to produce 'active' citizens altogether, while in others its effects reach far beyond labour activation, such as when digitalisation and conditionality destabilise a community's capacity to collectively demand change. This disjuncture between the aims of 'active citizenship' and the lived experiences of citizens leads us to argue that while 'conversion' in the case of UC was not itself a radical break in terms of the structure of social security, it has, and perhaps counter-intuitively so, radically affected state, citizen and market relations. This is because UC amounts to a profound realignment of welfare policy - one which centres social security more squarely on activation and which re-commodifies labour not by removing the state from the market but by turning the state itself into a heightened dispenser of insecurity and risk.

To develop these points, our study brings together insights from existing quantitative research and original ethnographic fieldwork. This mixed-methods approach enables us to generate unique insights by recording and analysing the effects of UC at both a microscopic as well as at a more general level. Our primary empirical work (carried out by Koch) is based on ethno- 
graphic work carried out in a middle-sized town in the south of England from April-December 2018. Fieldwork was conducted by Insa (first author) and her research assistant, Sasha East (herself a locally based resident with a background in community activism) and consisted of spending time with and talking to UC recipients, and interviews with and shadowing of local authority and third sector organisations that come into regular contact with UC claimants, including the local authority's welfare reform team, local foodbanks, community centres and advice centres. Through UC recipients, we were able to gain access to some of the information that the Jobcentre did not give us access to (including copies of so-called 'Claimants' Commitment Forms'). The quantitative analysis (carried out by Aaron - second author) draws on official statistics for claimant counts, employment outcomes (such as the proportion of people who are employed), and other relevant social outcomes, such as mental health. In what follows, we will first explain the expansion of 'active citizenship' under UC, before turning to its perhaps less evident effects on both individuals and on communities. The conclusion theorises UC as indicative of a broader shift from social security to state-sanctioned social insecurity in the contemporary era of welfare reform.

\section{EXPANDING 'ACTIVE CITIZENSHIP': BOTH UP AND ACROSS THE INCOME DISTRIBUTION}

Welfare conditionality is not a new invention. Successive British governments since the 1980s have expanded the number of people who are potentially exposed to the logics of work-related welfare conditionality. In 1996, the government of the day created 'Jobseekers Allowance' (JSA) which was an effort to 'tighten the screw' on 'work-shy' claimants of unemployment benefits. Yet, most of these earlier reforms were concentrated on specific groups: the unemployed, lone mothers, and to some extent, the disabled. By contrast, UC brings all of these groups together - exposing them to many of the same set of conditions - and then extends this logic to other forms of social security previously unexposed. Thus, UC combines six benefit payments into one overarching system (hence replacing Employment and Support Allowance, Jobseeker's Allowance, Housing Benefit, Working Tax Credits, Child Tax Credits, and Income Support Allowance by a single 'credit') (Timmins, 2017). These six forms of social security cover the major mechanisms through which the British government provides financial support to low income households. The effect has been to expand the scope of welfare conditionality to a far broader population than ever before. This has worked in both horizontal and in vertical ways: both 'across' the range of categories of welfare claimants (by generalising across a range of different benefits) and 'up' the income distribution (by including not only those out of work but a much broader section of the low-income, but working claimant population).

Those moved onto UC are made to comply with a logic of labour activation as a condition for receiving state support (Patrick, 2017). UC assumes active citizens who are willing and able to work a specific number of hours per week and earn a certain amount from their work. Once signed on, and in an attempt to mirror the logic of 'real' wages, the UC system is designed with a delay built in between the moment when people first sign-on and when they receive their first benefits. Often little consideration is given to personal circumstances or the situations some claimants face (Cheetham et al., 2019). Any potential UC claimant has to sign up to and 
continuously perform a set of duties that is determined, in a discretionary manner, with the individual's jobcoach. In practice, however, this process is led by the state's expectations of what claimants should do. This set of duties is defined in the 'claimant commitment' form, best described as an individualised social contract between a claimant and the state that specifies the core duties of the claimant as defined by their individual jobcoach. Take the case of Tyrese, a mixed-race white-African Caribbean 24-year-old young man, a personal trainer and coach, who was experiencing a period of unemployment following a close family member's death. Figure 1 is the claimant commitment form he was required to sign when he first registered for $\mathrm{UC}$

Tyrese had no option but to agree to the work regime specified in the form, which required him to pick up any job for 'minimum wage or more' and to 'start work immediately', and located within 90 minutes of travel from his home address. Tyrese's own desire to work in a field for which he was qualified felt largely irrelevant. What is more, once signed on, he had to learn to navigate an online welfare system that further institutionalises work at its core, by continuously proving to his job coach that he was seeking work, signing up to agencies, doing online job-related searches, recording all of his activities in an online journal, and performing these tasks for 35 hours every week. Tyrese was aware that the terms imposed on him were arbitrary: his friend had only been asked to register with 3 agencies, for example, instead of 5 . Yet, he had no choice but to comply. Tyrese had regular interviews with his allocated jobcoach where he felt the sessions were intended to 'catch him out' rather than help him find work. Failure to live up to his duties results in a 'sanction', which is the term given by the government to refer to cuts in, or complete loss of, benefit payments, which is usually for one month but can last up to 6 months (although it was up to three years at one point).

What makes the process of becoming 'active' even more strenuous for many is the fact that claimants have to do most of their work online. UC was the first major government service in the UK to be made 'digital by default'. Each claimant is given an ID number to manage their account. This account consists of four sections, including a 'to do list' which sets out a claimant's responsibilities; a 'journal' section where the claimant writes regular progress reports and communicates with their jobcoach; a section where a claimant can 'report a change' to their personal circumstances; and a final section, recently added, which allows claimants to request an advance (loan) as UC is paid 5 weeks in arrears. Criticisms that the 'digital by default' system constitutes an obstacle, rather than an enabler, are well known, including that UC has built a 'digital barrier' (Alston, 2018) that obstructs access to benefits, particularly for older people, those who do not speak English, and persons with disabilities. Despite a high overall roll-out of broadband internet, only 54 per cent of claimants in a government conducted survey were able to apply online independently, without assistance, in 2018 (Alston, 2018). Tyrese, for example, did not have internet at home and so had to take a bus all the way into town to do his job-searches in the public library, often having to wait in a queue to get access to one of their computers for a limited period of time. 


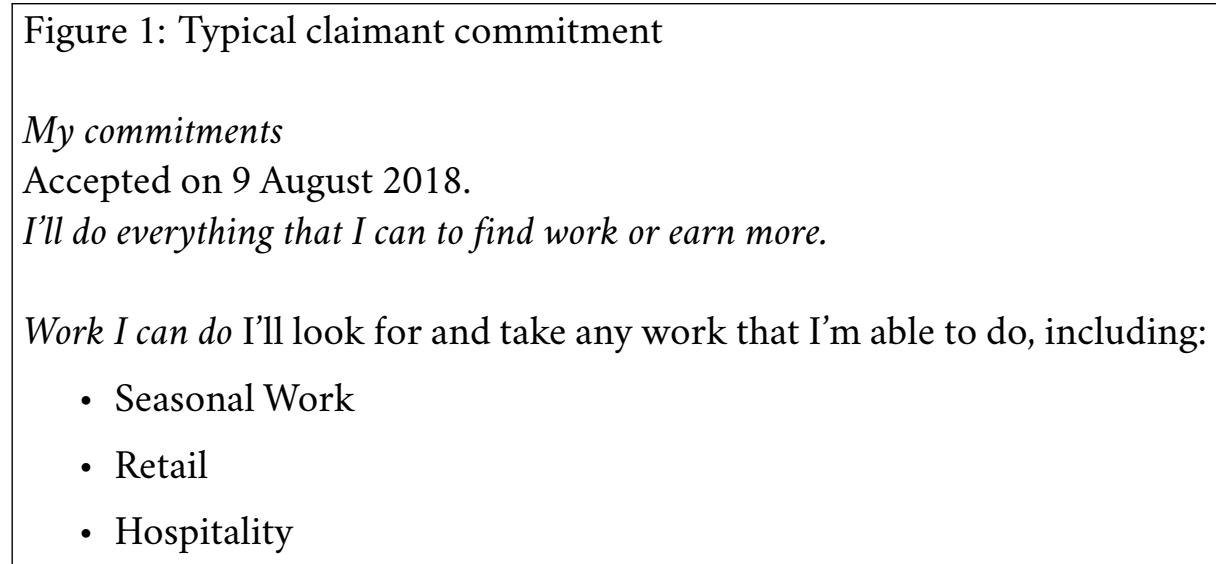

I'll also apply for any jobs recommended by my work coach. I'll look for full-time work for the minimum wage or more.

My availability

I'm available for job interviews immediately and will participate fully. I'm available to start work immediately.

Travel to work

I can travel up to 90 minutes to work.

What I'll do

I'll normally spend 35 hours a week looking and preparing for work. I've agreed with my work coach that I'll:

- Using online job sites - CV Library, indeed, daily info and applying directly on employers

- Handing my CV out to employers

- Sign up to 5 agencies

Extra activities

I haven't discussed any extra activities.

Meetings with my work coach

I'll attend and take part fully in all meetings with my work coach. I'll tell my work coach immediately if I can't do this.

Using my online account

I'll sign in to my online account often to:

- complete all activities in my to-do list

- report changes to my circumstances promptly, including changes to work. If I can't get online, I'll report any changes by calling [the Jobcentre's number] 
In sum, claimant's commitment forms, work-search related duties, threats of 'sanctions' and 'online by default' are the ingredients of a repurposed social security system that is targeting an ever-bigger claimant population both 'up' and 'across' the income distribution chain. Judged from this vantage point, the creation of UC can be read as a project of conversion which translates the aims of these legacy benefits from being concerned with providing economic security (in whatever imperfect or limited ways) to a system that creates active citizens in an attempt to reconcile the tension between welfare retrenchment and a political impetus to keep social security systems intact. However, creating 'productive' members of society has not been a smooth process, as the implementation of UC has been accompanied by messiness, chaos and sometimes outright failure that flies in the face of any singular logic of active citizenship.

\section{SETTING PEOPLE UP TO FAIL: UC'S IMPACT ON INDIVIDUALS}

While the government has heralded the introduction of Universal Credit, it quickly became clear that its introduction, transition, and workings were riddled with contradictions and problems. Much of this criticism has centred on sanctioning practices authorised under UC. Until recently, sanction rates under UC have been consistently higher than they were in the JSA system (Adler, 2018). Among all UC claimants, rates of sanctions were in 2019 between 2-3\% compared with rates of $0.5 \%$ and $0.04 \%$ among JSA and ESA claimants, respectively. Part of the explanation for these differences between JSA and UC sanction rate is that UC claimants are more likely to fail to adhere to their claimant commitment, with a large part of these sanctions being given for missing interviews. Furthermore, data from a DWP evaluation suggested that between $40-50 \%$ of UC claimants believed that at least some of the actions in the claimant commitment did not 'take account of personal circumstances' and were not 'achievable' (Adler, 2018). For example, two thirds of single parents were not aware there were 'flexibilities' that can allow them to tailor conditionalities to their circumstances (Coleman \& Riley, 2012).

That sanctions attached to UC may be penalising people who are in many cases unable, not unwilling, to live up to the expectations of this new state-citizen relation (Work and Pensions Committee, 2015) remains a concern. Thus, 'there remains a danger that some vulnerable individuals are being "set up to fail" [by the new conditionality regime]' (Work and Pensions Committee, 2015). Indeed, in quantitative cross-local authority analyses, sanction rates appear higher in areas where there were more disabled and lone parent JSA claimants, suggesting the inflexibility within the regime of conditionality is leaving some claimants systematically more likely to fall foul of these expectations (Reeves \& Loopstra, 2017). What is more, sanctions appear to be given on a discretionary and sometimes seemingly arbitrary basis. Tyrese's case provides an illustration. In November 2018, Tyrese was sanctioned, when he looked for work through only 3 instead of the five recruitment agencies. The resulting cut in benefit payments left him in a dire situation, forcing him, like many other UC claimants (Dwyer \& Wright, 2014; Loopstra, Fledderjohann, Reeves, \& Stuckler, 2018) to find a foodbank to rely on basic necessities and negotiating access to it through a formal referral process, which was not often straightforward (Loopstra, Lambie-Mumford, \& Fledderjohann, 2019; Reeves \& Loopstra, 2020). Jayne, the founder of the town's first church-run foodbank also blamed the recent spike in foodbank users on UC sanctions. She recalled a particularly harsh case of sanctioning: 
I had a girl come in last week, she had had an epileptic fit on the day when she was supposed to turn up at the Jobcentre. So, for her the problem was not getting UC, but that she didn't turn up when she was expected to. She was sanctioned in May and she went to appeal with a letter from her doctor, and I think she has another appeal coming up this week. So, from May until now [end of September] she hasn't been getting any payments. And that is because she genuinely couldn't be there for her appointment... When you talk to people here, they always say that sanctions are unfair. It's too long, the period you get sanctioned for, and the consequences are really draconian...

Jayne's statement that the consequences of sanctioning are 'really draconian' is supported by recent studies. Sanctions frequently leave people in very difficult economic circumstances, particularly those who were already economically precarious (Dwyer \& Wright, 2014; Loopstra et al., 2018). Moreover, the consequences of being sanctioned can cascade into other areas of people's lives. Many people on UC are now in debt to the state because of loans they have received from the government to cover living expenses while they were waiting for their payments to start or because they requested additional help to cover their sanction. These people are often receiving less than the official benefit scales so they continue to experience prolonged material deprivation. Many of them are in debt to other people or organisations (including loan sharks) too. If claimants are unable to meet the conditions of welfare receipt, resulting in a sanction, this may deepen the degree of social exclusion faced by vulnerable groups.

Debt, however, is not only caused by sanctions. Both delays and monthly fluctuations in payments can also create financial pressures even when claimants have not breached their claimant commitment. For example, the UC system in England is designed so that claimants need to wait 35 days before they receive their first payment. And while the government has made 'advance payments' available to help claimants bridge the initial period, this comes as a loan which is deduced - alongside debts to third parties - from subsequent monthly payments, thus potentially leaving claimants without enough money in their accounts to pay their bills and rent. Another potential pitfall relates to the rigid imposition of salaried work onto the experience of low-wage or precarious work. Monthly incomes for those in low-wage work often fluctuate considerably from month to month and 'pay-day' is rarely on a specific day of each month (Hills, 2014). This incongruence between UC and the lived experience of low-wage work can create 'troubling underpayment[s]' in some months because 'their paydays and assessment periods do not coincide' (Alston, 2018). All of these state-sanctioned uncertainties are built into UC and may undermine a claimant's connection with the labour market and push claimants yet further from what the government calls 'work readiness'.

Many of these themes are illustrated in the case of Nicola, a white British woman in her thirties who worked as a carer in a nursery on a zero-hour contract (Koch, 2020). Nicola had fallen into rent arrears due to fluctuating UC payments. She was referred by her jobcoach to the local government's welfare reform team, which had initially been set up to help clients cope with welfare reforms, including the transition to UC. At the meeting with a case worker, Nicola explained that the stress of having to deal with fluctuating payments, the rent arrears that this 
had caused her, and the ever-present threat of eviction had put her in a 'bad mental space'. Between the various pressures she faced, she hadn't had the time to look for an alternative job that would pay more (nor is it certain that such a job exists for those who come with few or no professional qualifications). The case worker gave Nicola advice on how she should enrol on money management courses, as her UC payments were higher than that of many people's wages and she should be able to manage her money better. Nicola got angry. She started shouting at the officer, telling her that she did not need money advice, that her whole problem was that she did not have enough money in the first place, and that she was sick of 'people on benefits being treated like morons'. She stormed out of the meeting, left to solve her debt problems on her own.

In this instance, the application of a unified rigid logic of social security implied by UC once more failed to produce the uniformity of governance and active labour participation in the way it had been intended. In the case of Nicola (and many other claimants), the administrative changes had not simplified her life but rather caused unexpected hardship potentially exposing her to the risk of eviction and having her children moved into care (a common consequence of homelessness). It had also taken a toll on her mental health, leading her to experience heightened levels of anxiety, which in turn, can push people further away from the labour market (Barr et al., 2016; Reeves, 2017). Viewed together, this evidence then indicates that there is likely to be a non-trivial group whose job prospects are undermined by the administration of UC. And this is what frontline workers worried about: that UC would fail to help many claimants into 'independence'. Far from creating 'active citizens', the introduction of UC then also produced its opposite effects: citizens who are 'set up to fail' because of the imposition of the expectations and norms of salaried work onto those moving between low-income and insecure work. But the story does not end here: yet another, and perhaps less obvious but deeply corrosive, effect of UC concerns the way it affects not just individuals but communities - the very structures of social reproduction that are central to building collective resistance.

\section{UNDERMINING COLLECTIVES: UC'S HIDDEN SOCIAL HARMS}

Cathy was a white working-class woman in her late forties living in a two-bedroom councilowned house on the edges of the town. Insa (first author) had come across her name while doing research on a neighbouring and predominantly working-class estate. Cathy was concerned about an impending regeneration project that could displace local people and lead to gentrification. To express her concerns, Cathy had produced a small flyer, printed in blackand-white, with the words 'social cleansing, not social housing' written on top. Insa had asked a mutual friend to arrange a meeting with her, and one evening, the three of them met in a pub. To Insa's surprise, when Cathy turned up, she did not want to speak about the campaign, less even of her own involvement in it. Later in the conversation, Cathy opened up about her reluctance: she had recently been moved onto UC, and felt that she had to be 'careful' about staying under the radar. She was not in a position to take any risks at the moment. 'Back in the 1990s, you could be on the dole and use your benefits money to do political activism, but today you can't do that, you cannot do that anymore. Activism is now a privilege of the middle classes'. 
Cathy's sense that being on UC is incompatible with her activism - whether this is to do with regeneration or, indeed, UC itself - can be read as a reflection on the practical commitments that UC entailed: as shown above, the duty to continuously 'prove' one's efforts to find work is incredibly time-consuming, meaning that claimants literally do not have time to get involved in other projects aimed at the social good (including activism). She contrasted her current situation with the 1990s when requirements under JSA had been less strenuous. Her words also betrayed a fear of negative repercussions that might result from engaging in activities that could be considered anti-systemic and critical of the authorities. Indeed, this was frequently mentioned by claimants: a fear of being 'caught out', coupled with a perhaps unrealistic sense that they were constantly monitored and watched by 'Them' - the generic term people sometimes used to speak about anyone in power who they were dependent upon (Koch, 2018). This was reinforced by the digital nature of UC, and the fact that, at least in theory, jobcoaches could be in contact with claimants via their phone or a computer at any point of the day, by communicating with them via the online account. The fact of not being able to escape the controlling gaze of state officials (while simultaneously not being able to physically see them) then created a situation not unlike a Foucauldian panopticon where people could never know if anyone was watching them.

And there are yet further reasons why claimants like Cathy might prefer to keep quiet. Cathy spoke of how she did not have the opportunity to meet many people in her situation with whom to get together as a group. She spent much of her day on her own applying for jobs. Furthermore, the places where she could meet other UC claimants, including Jobcentres or foodbanks, were highly institutionalised or stigmatised settings: the Jobcentre, where claimants went for interviews with their jobcoaches, was described by claimants as having a 'prison like' atmosphere, with people being searched upon coming in, and having to ask for permission to use the public bathrooms. Similarly, many people who use foodbanks report feeling a sense of shame (Purdam, Garratt, \& Esmail, 2016). Shame and stigma weaken social networks and because many people rely on such networks to find work, this stigmatisation may deepen the degree of social exclusion already faced by those who are out of work. Indeed, while staff in the foodbank that Insa (first author) shadowed did their best to create a convivial atmosphere, arranging chairs and tables for people to sit around, have cups of tea and a biscuit, often people remain seated on their own waiting for their food parcels to be ready to collect, or stayed solely in the company of the people that they had come with.

Of course, informal spaces of socialising continue to exist in communities where welfare claimants live and which provide less formalised and judgmental spaces. However, the deleterious effects of UC are magnified precisely because they are embedded in a broader project of establishing a form of austerity governance through diminishing the state's involvement in these communities (Koch, 2018). For example, while the government has made funding available for digital service and budgeting advice, it is far less willing to support community-based collective activities aimed at serving the same demographics of citizens. Since 2010, local authority funding has been radically cut, and funding for smaller organisations and institutions - like community centres, youth clubs, local libraries tenants and resident's groups - have been particularly hard hit (Clayton, Donovan, \& Merchant, 2015; Koch 2020). The closure of local libraries across the country is particularly pernicious in the context of the wider move to 'digital by default' be- 
cause libraries were a space of free internet access. When speaking to an advice worker about the effects of UC, she was at pains to point out that it could not be read in isolation from austerity reform. While she was referring to the impact of these reforms on families and individuals, the same could be said of the impact of funding withdrawal on community structures:

What gets me is that there is a lot of talk of UC but what gets forgotten are all the previous changes that people have had. Like to do with the local housing allowance, the bedroom tax, the benefit cap... The big problem [with UC] is that it combines with all the other punishing measures which came into place before it. It combines with sanctions, with arbitrary rules that are designed to punish, with huge reductions to do with the advance payments... We used to be able to guarantee, at least on paper, that if someone got all the benefits that they were entitled to, they could have a balance sheet and survive. You can't make a balance sheet with people now.

Where community facilities have managed to remain open, they have often been turned into watered down means-tested services. On the estate, for example, where this advice worker was based, the family centre - previously offering a universal service - was turned into a referralonly service that caters for 'problem families'. Again, stigma attached to a 'problem-based service' means that few, if any, families want to be seen going into the centre, preferring to make do without professional support. Indeed, when speaking to Cathy, she was bitter that only (and typically larger, well-resourced and established) groups with independent funding were able to not 'sell out' or even keep going: 'activism is now a privilege of the middle classes'. Recent history seems to back her up, middle class activism is alive and well, with prominent strikes by doctors and academics alongside huge anti-Brexit protests (Pushkar, 2019). There has been far less collective resistance to welfare reform.

We do not wish to overstate the point: even in the most marginalised communities, grassroots initiatives have not entirely vanished and people continue to mobilise against the odds. On the estate where Cathy's flyer about the regeneration initiative had been passed out, a local independent debating group, a refugee support group, an active church community and various groups housed in the community centre were active. And this is not to even mention the informal networks of exchange central working class communities (Mollona 2009; Koch et al. forthcoming): informal exchange networks continue to be strong, as people lend each other money, put each other up in homes, often in the face of evictions incurred from rent arrears; give each other support in keeping up with benefit forms and online diaries; and accompany friends and family members to appointments in Jobcentres, health assessment for disability benefits, and to the foodbank, to mention just a few of the most stigmatising places that welfare claimants had to frequent. What is more, frontline services workers often stepped in to become spokespeople for those most harshly hit by austerity reform. Some of the frontline workers in the advice centre, the local credit union, the church and the community centre counted among the most outspoken advocates of austerity criticisms, seeing it as their role not only to dispense practical advice but to lend people a voice. 
And yet, notwithstanding these efforts, the point still stands: UC and other cuts to local services are about further individualising not collectivising state support and responses to them. And this is perhaps the most pernicious, yet also most difficult to quantify impact of UC beyond the stated aim of labour activation: its effects on the everyday social reproduction of local political life. The history of social movements shows us that resistance emerges out of shared experiences of particular status groups located in a particular geography (Barnes, 1995). These status groups are the product of sustained interactions by those in shared socio-economic contexts that create a form of organisation with common interests. Social networks have obviously changed the nature and structure of these groups and how they inform the creation of social movements, with online platforms and social media playing a key role in mobilising groups, such as the Arab spring movements (Ketchley, 2017). Still, the degree of solidarity and shared identity necessary to motivate action frequently remains rooted in offline connections that are embedded in particular communities (Harlow, 2012). The digitalisation of UC, in a broader context of austerity reforms, undermines the creation of these collective responses because it reduces the availability of sustained interactions in daily life. In the end, then, we can see how welfare reform generates once more its own forms of failures, this time on a community level.

\section{CONCLUSION: THE EXTENSION OF STATE-SANCTIONED INSECU- RITY}

Governments confront a central challenge at the heart of the welfare state: how to reconcile an ever-greater drive towards welfare retrenchment within the political limits of carrying out this policy programme amidst strong pressure to protect existing social security systems. One way in which states reconcile this tension is through a process of conversion (Thelen 2003), whereby policy makers redirect existing institutions toward new purposes. In the case of UC, this was done through the mantra of 'active citizenship' as an ever-larger population was expected to engage productively with the labour market, while still being offered a minimum level of social security protection. However, the process of converting existing social policies to meet the aims of active citizenship has not been straightforward. On the contrary, the redirection of state machinery has played out in unexpected, chaotic and often disastrous ways. UC has created uncertainty and precariousness as the norms of salaried professionals imposed onto low-wage workers can be hard to meet amidst the uncertainties of life in the low-pay/no-pay cycle (Shildrick et al 2012). UC claimants also routinely face delays in payments, sanctions, and ensuing debt that impacts upon their ability to be productive participants in the labour market. And, social security has become even less personal, as the 'British welfare state... gradually disappear[s] behind a webpage and an algorithm' (Alston 2018).

Our analysis adds to the raft of emerging criticisms on UC (Alston, 2018; Barnard, 2019), which has focused on its punitive welfare logic (Reeves \& Loopstra, 2017), the system of sanctioning (Adler, 2018; Dwyer \& Wright, 2014; Loopstra et al., 2018), its 'digital by default' set up (Alston, 2018), and its uneven effects on the most vulnerable sectors of the population (Reeves, 2017; Reeves \& Loopstra, 2017). It does so by starting not with abstract policy but rather with an 'actually existing politics' (Spencer 1997) to illuminate the complicated ways in which centrally devised policies come to interact with local histories (Bear, 2013; Shore \& Wright, 2003). By 
drawing on the actual experiences of citizens, and in particular the chaos and failures produced by UC, our analysis is firmly embedded within an anthropological perspective on the 'everyday state' (Alexander 2000; Fuller and Bénéï 2000; Koch 2019; Spencer 1997; Thelen et al 2014). Thus, the administrative changes associated with UC have had material consequences on the lives of claimants and their communities that go far beyond, and in some cases actively against, the aims of labour activation. What is more, and much more dangerously even in the long run, UC has had wider effects on society as a whole as the digitalisation of welfare further destabilises the bases for collective community resistance in constituencies whose capacity for self-mobilisation have already been weakened by years of austerity rule, on top of decades of economic and political dispossession (Koch 2018).

By adding nuance to existing criticisms of UC, our contribution is not just empirical, however. Rather, our analysis also enables a conceptual critique of the 'state of the welfare state' (Koch and James 2020). Thus, we argue that the process of welfare conversion implied by UC has not merely 'privatised' risks by pushing citizens ever more tightly into the realms of the market, as commonly assumed in critiques of neoliberal reform (Cain, 2016). Rather, its most profound, if perhaps paradoxical impact, lies in the way that it has preserved an idea of collectivised risk, albeit one that also effects its own failures. This is, of course, not to say that the challenges that UC was meant to solve are new. As we have stressed, the tension between fighting welfare retrenchment and commodifying labour has been central to the welfare state, becoming increasingly prominent in the 1980s and further intensifying since the Great Recession in 2008, as right-leaning parties have committed to reduce what was perceived to be government profligacy in the face of roaring public debts. Here, we argue that the process of conversion that was effected by this tension has amounted to a qualitative shift in the welfare state - one which is fast turning social security into a form of state-sanctioned social insecurity by deploying the mechanisms of state administration in the production of insecurities more commonly associated with the market. It is this social insecurity that constitutes the core ingredients of a particular paradigm of governance, one which feeds off its requirements for productivity (central in the idea of 'active citizenship') as much as it does on the impossibility of its realisation.

Our critique of the 'state of the welfare state' has centred on Universal Credit. But the implications of our argument reach beyond these particularities. Conceptually, it adds to the emerging critique that neo-liberal welfare reforms have not amounted to a withdrawal of the state - but rather the opposite, its expansion, albeit in uneven ways into the lives of the most marginalised citizens (Bruff 2014; Wacquant 2009). And it helps to shed light on similar developments elsewhere. For example, the notion of state-sanctioned social insecurity also helps us think through other areas of social security policy in the UK, including the pressing issue of financial support for the elderly, which has faced similar tensions between rising spending and cutting back entitlements. Indeed, the British Conservative party's proposal in the 2017 general election to reform social care provision could be viewed as a state-sanctioned effort to increase insecurity by making government help conditional (Cowley et al. 2018). More broadly, state-sanctioned insecurity might also be relevant to other countries facing similar challenges. This does not mean, of course, that other countries will pursue their own versions of UC but what we would expect to see is countries converting their social security policies 
toward institutions which, by design, create insecurity and precariousness. Even just a cursory glance shows that such changes have already been happening, with some countries increasingly pursuing policies which do not reduce entitlements but which limit eligibility and increase conditionality (Immervoll \& Knotz 2018). The US's welfare reforms under Clinton were, on this reading, a kind of policy conversion aimed toward addressing this tension (Somers \& Block 2005). And following the economic crisis in 2008, Latvia, Hungary, Czech Republic, Greece, Italy, and Norway all adopted a similar approach and, in effect, pursued a policy of creating state-sanctioned insecurity (Immervoll \& Knotz 2018).

And yet, as radical and potentially far-reaching as the creation of state-produced insecurity - as distinct from market-led processes of risk creation - might be, it should not be seen as an inevitable outcome of our times. Such a view would imply a too linear view of history as well as of the intentionality implied by these projects. The case of UC once more illustrates the point. Even if, from the point of view of those affected by welfare reform, the negative impact of UC makes it indistinguishable from austerity-led welfare reform policies, it is important to remember that its original impetus was distinct from the latter (Millar \& Bennett 2017). While we do not doubt that at least among some policy makers at the time, institutional 'ignorance' (Slater 2014) and a lack of concern about evidence might have acted as a 'deliberate tactic to support the chosen policy direction' (Millar \& Bennett, 2017: 175), proposals for UC commanded support from a wide cross-section of political leaders, including those on the left. It follows that we cannot simply understand processes of conversion such as those implied by UC as the simple outcome of neo-liberal restructuring, conceptualised as deliberate projects of state-making, intended to 'punish the poor' (Wacquant 2009). Nor can we reduce their effects to the unintentional mechanisms of disciplinary rule, or the ever-unfolding logics of governmentality. Instead, UC represents an intensification of a historical process in which different and competing logics present in previous eras of welfare policy have become more central by interacting with the lived realities of marginalised citizens, while others have fallen away or become less prominent.

Yet, if we are correct in arguing that the shift to state-sanctioned insecurity cannot be reduced to political masterminding or, alternatively, to the workings of disciplinary logics alone, this also gives reason for hope: it is precisely this contingency which, in turn, opens the possibility for resistance to the commodification of labour - whether through explicit legislative change or more radical processes of grassroots mobilisation (Polanyi, 2002). For example, when sanction rates for UC rose between 2011 and 2014 parts of the media and some of those affected by these changes pushed back against this new regime of conditionality (Watts \& Fitzpatrick, 2018), and sanction rates came down. Moreover, across much of the world, social movements and actors have started calling for alternatives to the economic neo-liberalism in the UK (Robinson \& Sheldon, 2019) and across other places in the global north and the global south (Bear \& Knight, 2017; James and Koch 2020; Knight \& Stuart, 2017; Powers \& Rakopoulos 2019). However, when it comes to UC, collective grassroots protests have largely been missing or only been intermittent. As we have seen, this may well be because the shift toward UC is occurring amidst a far more extensive erosion of the capacity of claimants to make their voices heard, a partial manifestation of the democratic deficit which is plaguing British politics in recent years. This double-move may have fractured the conditions of social reproduction 
needed to resist this latest push toward commodification. To build effective resistance in the years ahead, urgent redress is needed.

Funding This research was part funded by a grant by the Rockefeller Foundation through the IGA (Institute for Global Affairs) and the Joseph Rowntree Foundation.

Acknowledgments We would like to thank Laura Bear, Fran Bennett and Matthew Donoghue for their helpful feedback on an earlier draft of this paper. We also thank all the participants who agreed to be part of this research. We would also like to thank our funders for their support, for our other team members, and Liza Ryan for all her support through the project. A special acknowledgment goes to Sasha East, research assistant and co-ethnographer, for her invaluable contributions.

Insa Koch is Associate Professor and Director of the Anthropology and Law Programme at the London School of Economics. Her research interests include the welfare state, the criminal justice system and democracy. Her monograph Personalizing the State (OUP, 2018) is an ethnography of state-citizen relations in austerity Britain.

Aaron Reeves is an Associate Professor in the Department of Social Policy and Intervention at the University of Oxford, a Fellow of Green Templeton College, and a Visiting Senior Fellow in the International Inequalities Institute at the London School of Economics. He is a sociologist with interests in public health and political economy. His work involves examining the causes and consequences of social and economic inequity, primarily in Europe and North America. 


\section{REFERENCES}

Alexander, C. (2000). Personal States. Making Connections between People and Bureaucracy in Turkey. Oxford: Oxford University Press

Adler, M. (2018). Cruel, Inhuman or Degrading Treatment? Benefit Sanctions in the UK. Palgrave Macmillan.

Agamben, G. (1998). Homo Sacer: Sovereign Power and Bare Life. Stanford, CA.: Stanford University Press.

Alston, P. (2018). Visit to the United Kingdom of Great Britain and Northern Ireland (Report of the Special Rapporteur on extreme poverty and human rights). Geneva, Switzerland: UN General Assembley.

Barnard, H. (2019). Where next for Universal Credit and tackling poverty? York: Joseph Rowntree Foundation.

Barnes, B. (1995). The Elements Of Social Theory. London: Routledge.

Barr, B., Taylor-Robinson, D., Stuckler, D., Loopstra, R., Reeves, A., \& Whitehead, M. (2016). "First, do no harm": are disability assessments associated with adverse trends in mental health? A longitudinal ecological study. J Epidemiol Community Health, 70(4), 339-345.

Bear, L. (2013). The antinomies of audit: opacity, instability and charisma in the economic governance of a Hooghly shipyard. Economy \& Society 42(3), 375-397.

Bear, L., \& Knight, D. M. (2017). Alternatives to Austerity. Anthropology Today, 35(5).

Bruff, I. (2014). The rise of authoritarian neoliberalism. Rethinking Marxism: A Journal of Economics, Culture \& Society 26(1), 113-129

Cain, R. (2016) Responsibilising Recovery: Lone and Low-Paid Parents, Universal Credit and the Gendered Contradictions of UK Welfare Reform. British Politics 11(4): 488-507.

Cheetham, M., Moffatt, S., Addison, M., \& Wiseman, A. (2019) Impact of Universal Credit in North East England: A Qualitative Study of Claimants and Support Staff. BMJ Open 9(7).

Clarke, J., \& Newman, J. (2012). The alchemy of austerity. Critical Social Policy, 32(3), 299_ 319.

Clayton, J., Donovan, C., \& Merchant, J. (2015). Distancing and limited resourcefulness: Third sector service provision under austerity localism in the north east of England. Urban Studies, 53(4), 723-740. 
Coleman, N \& Riley, T. (2012) Lone Parent Obligations: Following Lone Parents' Journeys from Benefits to Work. Research Report. 818. Department for Work and Pensions.

Cowley, P., D. Kavanagh, and W. Ball. (2018). Everything Changes in The British General Election of 2017. London: Springer: 177-202.

Dubois, V. (2009) Towards a Critical Policy Ethnography: Lessons from Fieldwork on Welfare Control in France. Critical Policy Studies 3(2):221-239.

Dwyer, P., \& Wright, S. (2014). Universal Credit, ubiquitous conditionality and its implications for social citizenship. Journal of Poverty and Social Justice, 22(1), 27-35.

Esping-Andersen, Gøsta. 1990. The Three Worlds of Welfare Capitalism. Cambridge: Polity.

Foucault, M. (2008). The Birth of Biopolitics - Lectures at the Collège de France, 1978-1979. (G. Burchell \& A. Davidson, Eds.). Basingstoke: Palgrave Macmillan.

Fuller, C. J., and V. Bénéï. (2001). The Everyday State and Society in Modern India. C. Hurst $\&$ Co. Publishers.

Hacker, J. S. (2004). Privatizing Risk without Privatizing the Welfare State: The Hidden Politics of Social Policy Retrenchment in the United States. American Political Science Review, 98(2), 243-260.

Hacker, J. S., P. Pierson, and K. Thelen. (2015). "Drift and Conversion: Hidden Faces of Institutional Change.” Advances in Comparative-Historical Analysis 180-208.

Harlow, S. (2012). Social media and social movements: Facebook and an online Guatemalan justice movement that moved offline. New Media \& Society, 14(2), 225-243.

Harvey, D. (2007). A Brief History of Neoliberalism. Oxford University Press.

Hills, J. (2011). The changing architecture of the UK welfare state. Oxford Review of Economic Policy, 27(4), 589-607.

Hills, J. (2014). Good Times, Bad Times: The Welfare Myth of Them and Us. Bristol: Policy Press. Immervoll, H., and C. Knotz. 2018. How Demanding Are Activation Requirements for Jobseekers. Vol. 215. OECD Social, Employment and Migration Working Papers. 215.

Ketchley, N. (2017). Egypt in a Time of Revolution. Cambridge: Cambridge University Press.

Knight, D., \& Stuart, C. (2017). Ethnographies of Austerity: Temporality, Crisis and Affect in Southern Europe. History and Anthropology, 27(1).

Koch, I. (2018). Personalizing the State: an Anthropology of Law, Politics and Welfare in Aus- 
terity Britain. Oxford: Oxford University Press.

Koch, I. (2020). The Guardians of the Welfare State: Universal Credit, Welfare Control and the Moral Economy of Frontline Work in Austerity Britain. Sociology 1-20 (online advanced publication)

Koch, I., \& James, D. (2020). The State of the Welfare State: Advice, Governance and Care in Settings of Austerity. Ethnos 85: 1-21 (online advanced publication)

Koch, I.; M. Fransham; S. Cant; J. Ebrey; L. Glucksberg; M. Savage (forthcoming). Social Polarisation at the local level: a four-town comparative study on the challenges of politicising inequality in Britain'. Sociology

Loopstra, R., Fledderjohann, J., Reeves, A., \& Stuckler, D. (2018). Impact of Welfare Benefit Sanctioning on Food Insecurity: a Dynamic Cross-Area Study of Food Bank Usage in the UK. Journal of Social Policy, 1-21.

Loopstra, R., Lambie-Mumford, H., \& Fledderjohann, J. (2019). Food bank operational characteristics and rates of food bank use across Britain. BMC Public Health, 19(1), 561.

Lowndes, V., \& Pratchett, L. (2012). Local Governance under the Coalition Government: Austerity, Localism and the "Big Society." Local Government Studies, 38(1), 21-40.

Marshall, T. (1950). Citizenship and Social Class, and Other Essays. Cambridge: Cambridge University Press.

McArthur, D. \& Reeves, A. (2019) The Rhetoric of Recessions: How British Newspapers Talk about the Poor When Unemployment Rises, 1896-2000 Sociology, 53(6): 1005-1025.

Millar, J., \& Bennett, F. (2017). Universal credit: assumptions, contradictions and virtual reality. Social Policy \& Society, 16(2), 169-182.

Mollona, M. (2009). Made in Sheffield: An Ethnography of Industrial Work and Politics. New York: Berghahn Books. OECD. (2019). Society at a Glance 2019. Paris: OECD Publishing.

Patrick, R. (2017). For Whose Benefit?: The Everyday Realities of Welfare Reform. Policy Press.

Pierson, P. (1994). Dismantling the welfare state?: Reagan, Thatcher, and the politics of retrenchment. Cambridge: Cambridge University Press.

Polanyi, K. (2002). The Great Transformation: The Political and Economic Origins of Our Time. Boston, MA: Beacon Press.

Powers, T., \& Rakopoulos, T. (2019). The anthropology of austerity: An introduction. Focaal, 2019(83), 1-12. 
Purdam, K., Garratt, E. A., \& Esmail, A. (2016). Hungry? Food Insecurity, Social Stigma and Embarrassment in the UK. Sociology, 50(6), 1072-1088.

Pushkar, P. (2019). NHS Activism: The Limits and Potentialities of a New Solidarity. Medical Anthropology, 38(3), 239-252.

Reeves, A. (2017). Does sanctioning disabled claimants of unemployment insurance increase labour market inactivity? An analysis of 346 British local authorities between 2009 and 2014. Journal of Poverty and Social Justice, 25(2), 129-146.

Reeves, A., \& Loopstra, R. (2017). "Set up to Fail”? How Welfare Conditionality Undermines Citizenship for Vulnerable Groups. Social Policy and Society, 16(2), 327-338.

Reeves, A., \& Loopstra, R. (2020). The Continuing Effects of Welfare Reform on Food Bank Use in the UK: The Roll-out of Universal Credit. Journal of Social Policy, 1-21.

Robinson, K., \& Sheldon, R. (2019). Witnessing loss in the everyday: Community buildings in austerity Britain. The Sociological Review, 67(1), 111-125.

Rose, N., O’Malley, P., \& Valverde, M. (2006). Governmentality. Annual Review of Law and Social Science, 2(1), 83-104.

Shildrick, T., R. MacDonald, C. Webster, and K. Garthwaite. (2012). Poverty and Insecurity: Life in "low-Pay, No-Pay" Britain. Policy Press.

Shore, C., \& Wright, S. (2003). Anthropology of Policy: Perspectives on Governance and Power. Routledge.

Slater, T. (2014). The Myth of 'Broken Britain': Welfare Reform and the Production of Ignorance. Antipode 46(4):948-69.

Somers, M. R., \& Block, F. (2005). From Poverty to Perversity: Ideas, Markets, and Institutions over 200 Years of Welfare Debate. American Sociological Review, 70(2), 260-287.

Spencer, J. (1997). Post-Colonialism and the Political Imagination. Journal of the Royal Anthropological Institute 1-19.

Thelen, K. (2003) How Institutions Evolve: Insights from Comparative-Historical Analysis. In Comparative Historical Analysis in the Social Sciences, ed. J. Mahoney and Dietrich Rueschemeyer. Cambridge: Cambridge University Press.

Thelen, Tatjana, Larissa Vetters, and Keebet von Benda-Beckmann. 2014. "Introduction to Stategraphy: Toward a Relational Anthropology of the State." Social Analysis 58(3):1-19.

Timmins, N. (2017). The Five Giants: A Biography of the Welfare State (Revised edition edi- 
tion). London: HarperCollins.

Tyler, I. (2020). Stigma: The Machinery of Inequality. London: Zed Books.

Wacquant, L. (2009). Punishing the Poor: The Neoliberal Government of Social Insecurity. Durham, N.C. ; London: Duke University Press.

Watts, B., \& Fitzpatrick, S. (2018). Welfare Conditionality. New York: Routledge.

Weszkalnys, G. (2011). Cursed resources, or articulations of economic theory in the Gulf of Guinea. Economy and Society, 40(3), 345-372.

Work and Pensions Committee. 2015. Benefit Sanctions Policy Beyond the Oakley Review. London: Department for Work and Pensions. 